\title{
境界の透過性による壁乱流の乱流変調 TURBULENCE MODULATION BY WALL PERMEABILITY IN A WALL-BOUNDED FLOW
}

\author{
横嶋 哲 ${ }^{1}$ \\ Satoshi YOKOJIMA \\ 1 正会員 博（工）静岡大学 准教授学術院 工学領域数理システム工学系列（† 432-8561 浜松市中区城北 3-5-1）
}

\begin{abstract}
A series of direct simulations of a fully-developed turbulent flow along a mesh-screen type permeable plate whose geometrical property is systematically changed is performed to identify the effect of wall permeability on wall-bounded turbulent flows. The present system includes as two extreme limiting cases the classical impermeable channel flow and the perfectly-permeable channel flow of Yokojima (J. Phys. Soc. Jpn. 80 (2011) 033401), which have an identical solution in the laminar state. The numerical experiment demonstrates that, by increasing the porosity of the plate or by decreasing the pore size, the coherent structures visualized near the boundary show a qualitative transition from the streamwise vortices ubiquitous in a wide variety of wall-bounded flows to thin vortical structures elongated to the transverse direction and the flow resistance is increased. These findings are in good accordance with those observed in the perfectly-permeable channel flow. It is also found that the drag is closely associated with the blowing/suction intensity through the mesh screen.
\end{abstract}

Key Words: Direct numerical simulation, turbulent channel flow, wall permeability, perfectly permeable wall, mesh-screen type plate

\section{1.はじめに}

固体壁上での流速境界条件 $\mathbf{u}=\mathbf{0}$ は，流体粘性によっ て壁接線方向の運動を抑える粘着条件と, 流体粘性の 有無に依らずに運動学上の制約として流体の壁の通り 抜けを禁じる不透過条件という, 物理的背景の全く異 なる制約が組み合わさったものである，すなわち，平 行平板間乱流 (チャネル乱流)をはじめとする粘着・不 透過境界を過ぎる壁乱流は，この 2 種類の制約の影響 を同時に受ける。これらの制約が壁乱流に及ぼす影響 を個別に理解するため, Yokojima ${ }^{1)}$ は理想的な透過性 を備えた平板間乱流（完全透過チャネル乱流）を計算 機上に創出し，通常のチャネル流と比べて飛躍的な抵 抗増大と混合促進, 瞬時レベルでの秩序構造の質的変 化をもたらすことなどを見出した。この研究は境界の 透過性が壁乱流に及ぼす影響を明白に示した点で流体 物理学的に意義深い反面, 数值実験でしか再現できな い極限理想状態が対象であるため, 工学上直接的に有 用な知見を得ることは難しい。

本研究では実在する透過性境界としてメッシュ状の平 板境界に注目し，これに沿った乱流場であるメッシュ状 透過チャネル乱流を検討対象とする（図-1）。メッシュ・ チャネル流ではメッシュ間隔 $S$, メッシュ素材幅 $W$ を変 えることで透過性の異なる平板境界が実現され， $S=0$ で通常のチャネル流, $W \rightarrow 0$ かつ $S \rightarrow 0$ (すなわち非 常に細い素材を用いて非常に目の細かなメッシュを組 periodicity imposed in $x_{2}$ as well as in $x_{1} \& x_{3}$

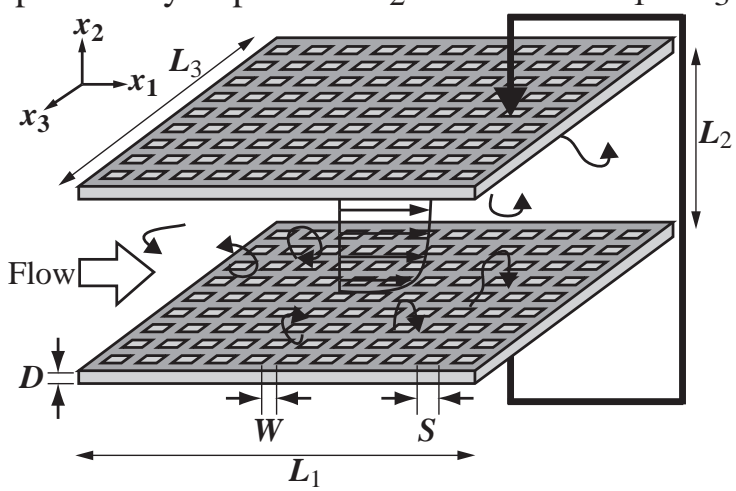

図-1 メッシュ・チャネル流の概略. 全ての方向に周期性が課 されており，上下に配置されたメッシュは同一境界を指 す.メッシュ間隔 $S=0$ の場合（本研究のケース M00-00, 表-1 参照）には古典的なチャネル乱流に帰着する.

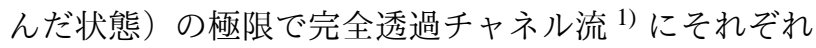
帰着する。また, 透過性とは独立に, 厚み $D$ によって 境界粗度の影響をコントロールできる。すなわちメッ シュ・チャネル流は一般的な壁境界の巨視的な特徴要素 である粗度・透過性・部分すべりが流れに及ぼす影響 の検討に適した系と言える.

本報では境界の透過性が壁乱流に及ぼす影響の理解 に焦点を絞る.すなわち境界の空隙率 $\phi \equiv S^{2} /(S+W)^{2}$ と空陌サイズ $S$ を系統的に変化させ, それらが流れ場 に及ぼす影響を明らかにする。樹木群や浸透床, 透過水 
表-1 検討対象としたメッシュ状境界の幾何学特性の一覧.

\begin{tabular}{cccccc}
\hline Case & $\phi$ & $S^{+}$ & $W^{+}$ & $S / \delta$ & $W / \delta$ \\
\hline M00-00 & 0 & 0 & $\infty$ & 0 & $\infty$ \\
M25-12 & 0.25 & 12 & 12 & 0.08 & 0.08 \\
M25-24 & 0.25 & 24 & 24 & 0.16 & 0.16 \\
M25-36 & 0.25 & 36 & 36 & 0.24 & 0.24 \\
M44-16 & 0.44 & 16 & 8 & 0.11 & 0.05 \\
M44-32 & 0.44 & 32 & 16 & 0.21 & 0.11 \\
M44-48 & 0.44 & 48 & 24 & 0.32 & 0.16 \\
M56-18 & 0.56 & 18 & 6 & 0.12 & 0.04 \\
M56-36 & 0.56 & 36 & 12 & 0.24 & 0.08 \\
M56-54 & 0.56 & 54 & 18 & 0.36 & 0.12 \\
\hline
\end{tabular}

制のように「透過性」や「境界粗度」が備わった複雑な 境界/障害物が遍在し，そういった流れをたびたび粗視 化して扱わざるを得ない水工水理学においては, 複雑 境界を表現する代表的な巨視的パラメータである「透 過性」と「境界粗度」の影響の理解とモデル化が強く 求められる. 本研究では議論のベースとなるデータを 生む数值実験は微視的に（細部まで正確に）行う反面, 議論の焦点は流況と境界特性を巨視的なレベルで関連 付けることにある.

\section{2. 実験条件と数値計算法}

数値実験（直接数值シミュレーション）は圧力勾配固 定の条件下で行った. 壁面平均摩擦速度 $U_{\tau}$ とチャネル半 幅 $\delta=L_{2} / 2$ に基づくレイノルズ数 $R e_{\tau}$ を 150 とした. 計 算領域は主流方向に $L_{1}=3.84 \delta$, 横断方向に $L_{3}=1.92 \delta$ を確保した。境界の空隙率 $\phi$ は $0.25,0.44,0.56$ の 3 ケー スを検討した。それぞれの場合にメッシュ間隔 $S$ を 3 段階に変化させ, 計 9 種類のメッシュ状境界を検討対 象とした（表-1）。ここではメッシュ間隔やメッシュ素 材幅が $x_{1}, x_{3}$ の両方向に等しい場合を考え，また，境 界粗度の影響を議論から排除するため, メッシュ厚 $D$ はゼロとした. 比較のため, $S=0$ として通常のチャネ ル乱流も同様にシミュレートした。

数值計算法には埋め込久境界法 (以下, IB 法) ${ }^{2,3)}$ を用 い，支配方程式を差分法で離散化した。本コードはこれ まで円柱群や円柱列を過ぎる流れ 4, 5, 6) や静水中の粒子 群の沈降現象 7) などに適用され，その基本性能が確認さ れてきた. 計算格子は全ての方向に $\Delta / \delta=2 / 150, \Delta^{+}=2$ で等間隔に配置した。これは今回採用した IB 法では, 埋め込まれた物体境界の近傍で等間隔な計算格子が必 要となることに依る。なお, 以下では壁変数（摩擦速 度 $U_{\tau}$ および動粘性係数 $v$ ) で規格化された物理量を上 付きの添え字＋を用いて $f^{+}$のように表す. 全ての方向 に周期性を仮定し，メッシュ状境界表面では粘着・不 透過条件を課した．次節以後に示す結果はそれぞれの

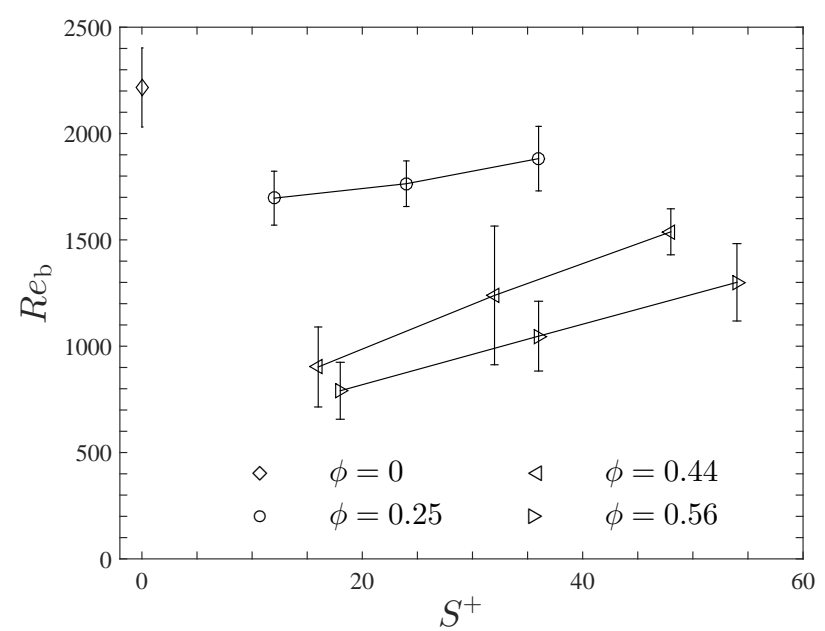

図-2 バルク・レイノルズ数の時間平均值（プロット）と標準 偏差（エラーバー）の境界幾何学特性依存性. ただし標 準偏差は 10 倍に拡大して表示.

ケースにおいて統計的に定常な状態に達した後の 4000 粘性時間以上に及ぶ系の観察に基づく.

\section{3. 瞬時渦構造とメッシュ境界での吹き出し/吸い込 み特性}

図-2 は各ケースで観測されたバルク・レイノルズ数 $R e_{\mathrm{b}} \equiv U_{\mathrm{b}} \delta / v$ の時間平均值と標準偏差を表す．ただし 標準偏差は 10 倍に拡大して表示した。これより，平板 境界の空隙率 $\phi$ が増す，またはメッシュ間隔 $S$ が狭い ほど流量が減る（すなわち抵抗が増す）ことが明確に 読み取れる。また，透過性の付加によって流量が大き く低下した場合にもその摇らぎはほとんど弱まらない. その結果，不透過なチャネル流では摇らぎ強度は高々 1\%程度であるのに対して，メッシュ・チャネル流では 2\%を超えるケースも認められた。

図-3 は速度勾配テンソルの第 2 不変量の等值面によっ て可視化された瞬時渦構造を示す。併せて主流方向の 変動速度 $u_{1}-\bar{u}_{1}$ のカラーコンターをいくつかの 2 次元 断面 $\left(x_{1}-x_{2}\right.$ および $\left.x_{2}-x_{3}\right)$ 上に表示した。赤（青） はその領域が平均流 $\bar{u}_{1}$ より速い（遅い）流体で占めら れていることを意味する。通常の不透過なチャネル流 では，図-3(a)のように，主流方向に伸びた管状の渦構 造が遍在し, 乱れの生成や混合促進, 摩擦抵抗の増大 に寄与することがよく知られている．管状渦によって その近傍ではスウィープやイジェクションが誘起され ていることが, 主流方向変動速度 $u_{1}-\bar{u}_{1}$ のカラーコン ターからも読み取れる。他方で完全透過チャネル流で は流路横断方向に引き伸ばされ，法線方向に非常に薄 い渦構造が境界に貼りつくように発生し, 通常のチャ ネル流とは質的に全く異なる力学機構が存在すること が報告されている ${ }^{1)}$.メッシュ・チャネル流では，空隙 率 $\phi$ が低い場合には通常のチャネル流と同様に主流方 向に軸を持つ管状渦が多数観察される（図-3(b)-(d)）も 


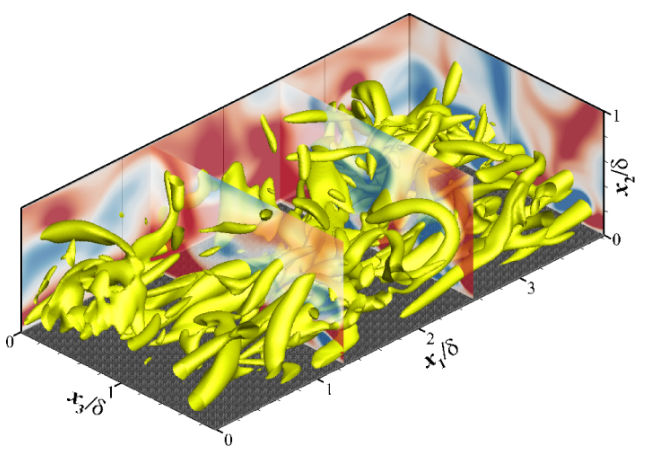

(a) M00-00, $\bar{R} e_{\mathrm{b}}=2217$.

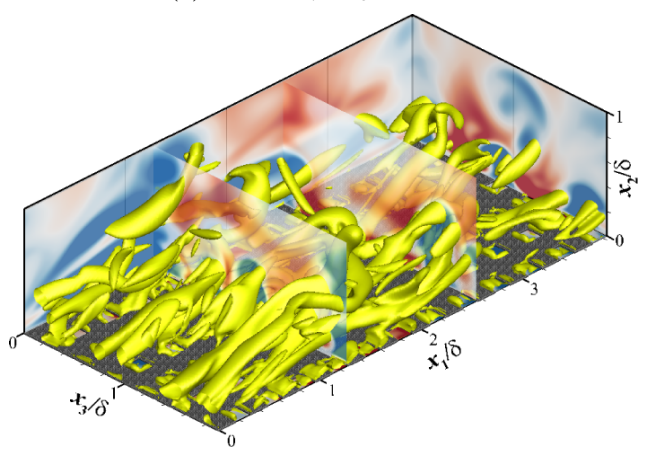

(c) $\mathrm{M} 25-24, \bar{R} e_{\mathrm{b}}=1764$.

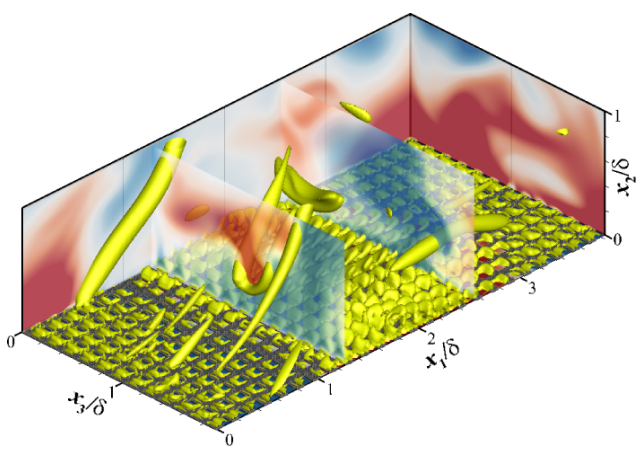

(e) M44-16, $\bar{R} e_{\mathrm{b}}=902$.

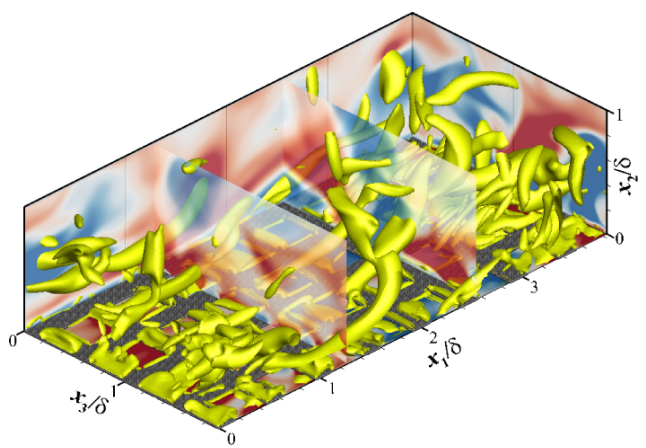

(g) M44-48, $\bar{R} e_{\mathrm{b}}=1538$.

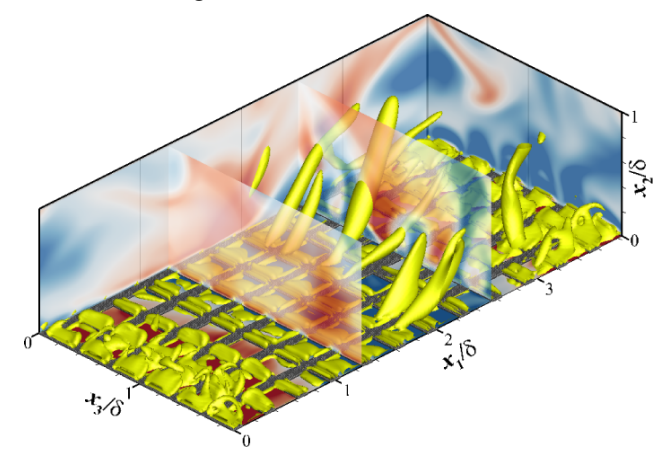

(i) $\mathrm{M} 56-36, \bar{R} e_{\mathrm{b}}=1047$.

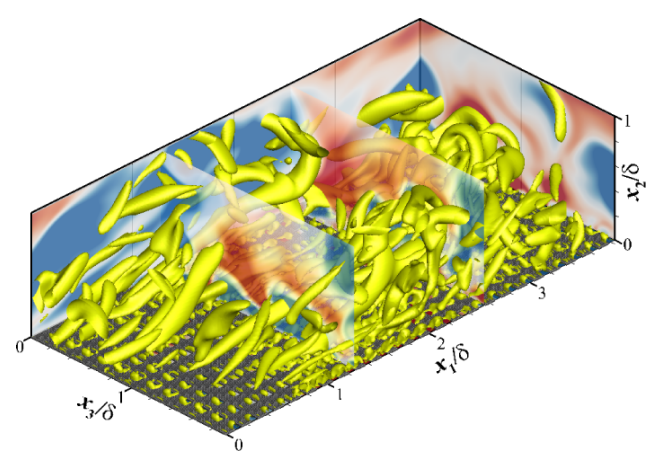

(b) M25-12, $\bar{R} e_{\mathrm{b}}=1696$.

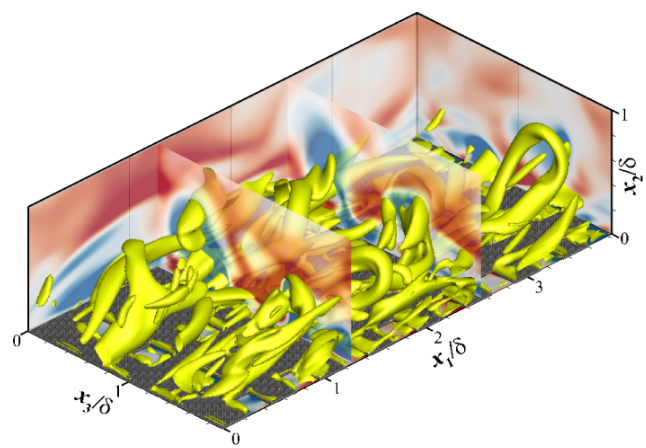

(d) M25-36, $\bar{R} e_{\mathrm{b}}=1882$.

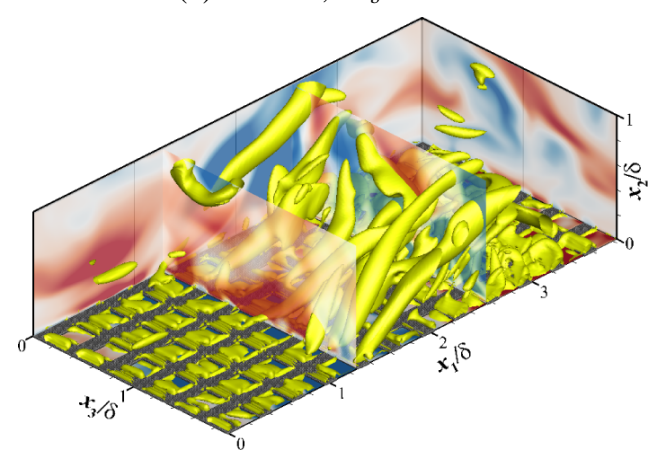

(f) M44-32, $\bar{R} e_{\mathrm{b}}=1239$.

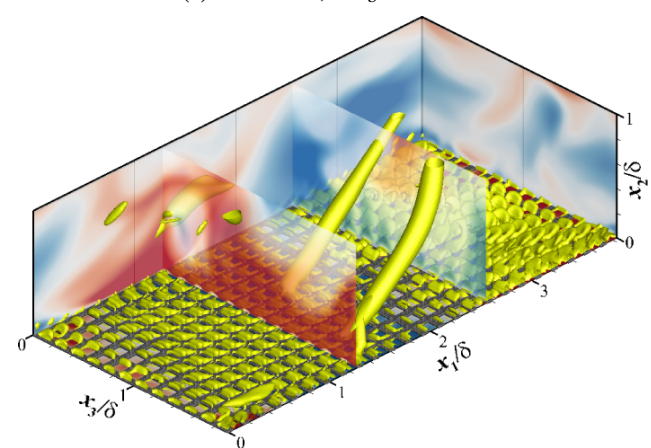

(h) M56-18, $\bar{R} e_{\mathrm{b}}=790$.

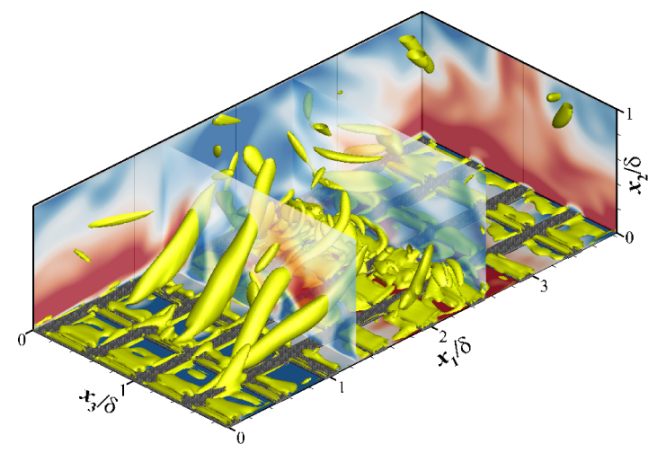

(j) M56-54, $\bar{R} e_{\mathrm{b}}=1300$.

図-3 速度勾配テンソルの第 2 不変量 $Q$ の等值面 $\left(Q^{+}=0.01\right)$ にって可視化された瞬時渦構造. 主流速変動成分 $u_{1}-\bar{u}_{1}$ の カラーコンターをいくつかの 2 次元断面 $\left(x_{1}-x_{2}\right.$ および $\left.x_{2}-x_{3}\right)$ 上で表示. 赤（青）は局所・瞬間的に平均流 $\bar{u}_{1}$ より速 い（遅い）流体の存在を意味. さらに $x_{2}=0$ の境界面では瞬時流速 $u_{2}$ の值を表示. 赤は吹き出し $\left(u_{2}>0\right)$, 青は吸い込 み $\left(u_{2}<0\right)$ をそれぞれ意味する. 


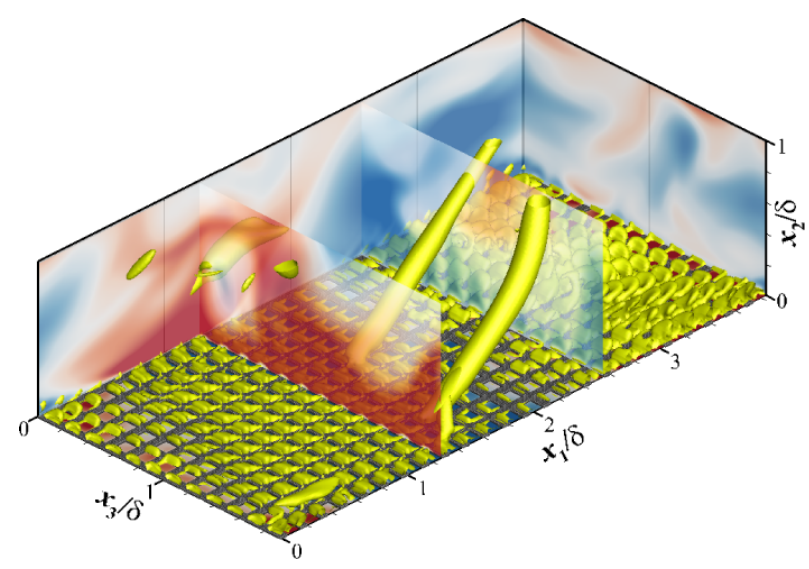

(a) a bird's-eye view of the coherent structures.

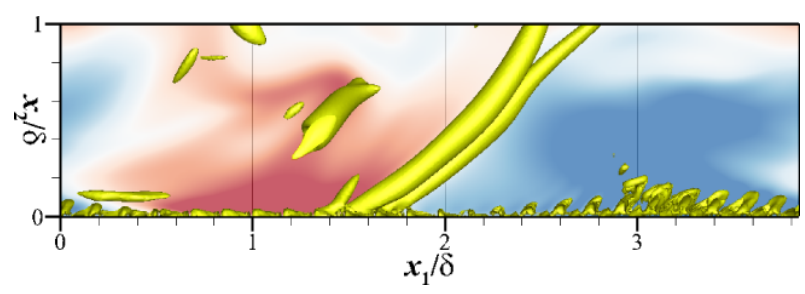

(c) a side view of (a).

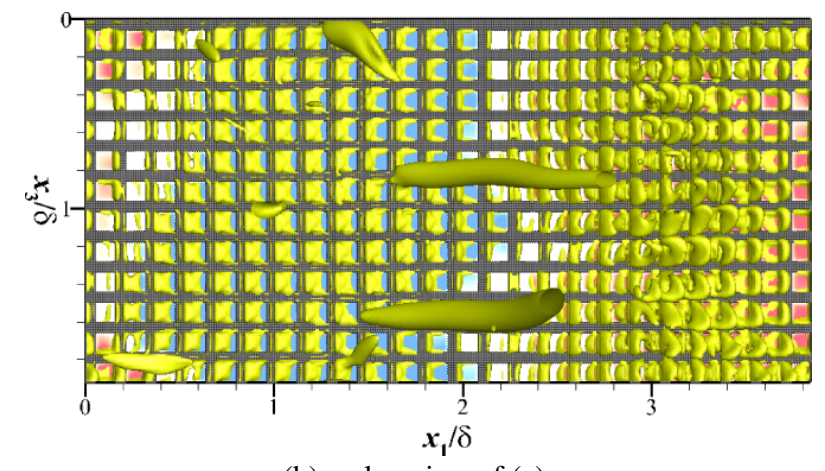

(b) a plan view of (a).

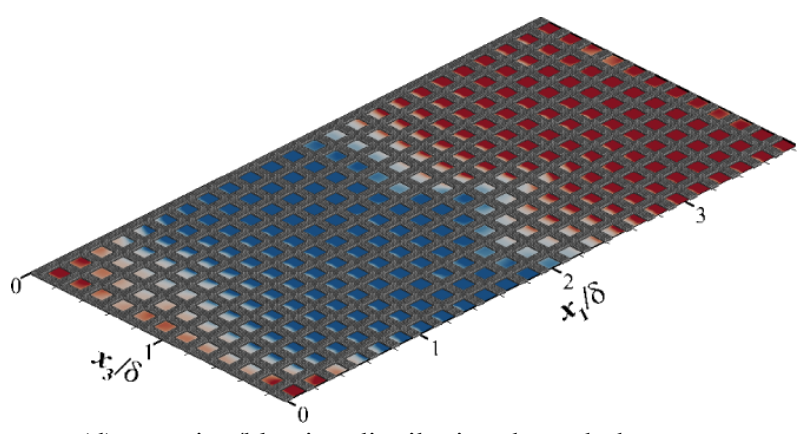

(d) a suction/blowing distribution through the pores.

図-4 ケース M56-18 において可視化された渦構造の空間分布の詳細とメッシュ空隙での吹き出し/吸い込み分布

のの, 空隙率が 0.44 (図-3(e)-(g)），0.56（図-3(h)-(j)） と増すにつれて管状渦が減少し，その存在に空間的な 偏りが認められる．特に空隙サイズが小さくなるにつ れてその傾向は強まり，メッシュ境界極近傍にのみ渦 構造が集中的に観察されるようになる.

図-3 の $x_{2}=0$ の境界面上のカラーコンターはメッ シュ空隙での瞬時流速 $u_{2}$ の分布を表し, 赤は吹き出し $\left(u_{2}>0\right)$, 青は吸い込み $\left(u_{2}<0\right)$ を示すものの, ケー スによっては管状渦の存在によって分布が見えづらい. この境界面での吹き出し/吸い込み現象と瞬時渦構造の 関係を明らかにするため, 本検討において最も完全透 過境界に近いケースである M56-18 において, 渦構造 の上面図 $\left(x_{1}-x_{3}\right)$ と側面図 $\left(x_{1}-x_{2}\right), x_{2}=0$ の境界 空隙内での瞬時流速 $u_{2}$ 分布を図-4 に示した。吸い込み 領域と吹き出し領域で観察される渦構造に質的な違い が明確に認められる. $0 \leq x_{1} / \delta \leq 2$ 付近の吸い込み部で は領域全体がスウィープな挙動を示し, 他方で吹き出 し部では領域全体がイジェクションで満たされる．前 者では高速流体によって乱流状態が活性化され，管状 渦の発生・成長が観察される. 吹き出し/吸い込みが流 路横断方向には概ね一様に分布し, 主流方向に交互に 発生する点は完全透過チャネル流における観察事実 ${ }^{1)}$ とよく一致する. 図-4で観られた特徵は M44-16 のよ うに空隙率が高く, 空隙サイズが狭いケース全般に当 てはまるものである.

図-4に示したメッシュ空隙の吹き出し/吸い込み速度 のメッシュの幾何学特性に対する依存性を図-5に示す. この乱れ強度 $u_{2, x_{2}=0}^{\mathrm{rms}}$ は 4000 粘性時間超および $x_{1}-x_{3}$

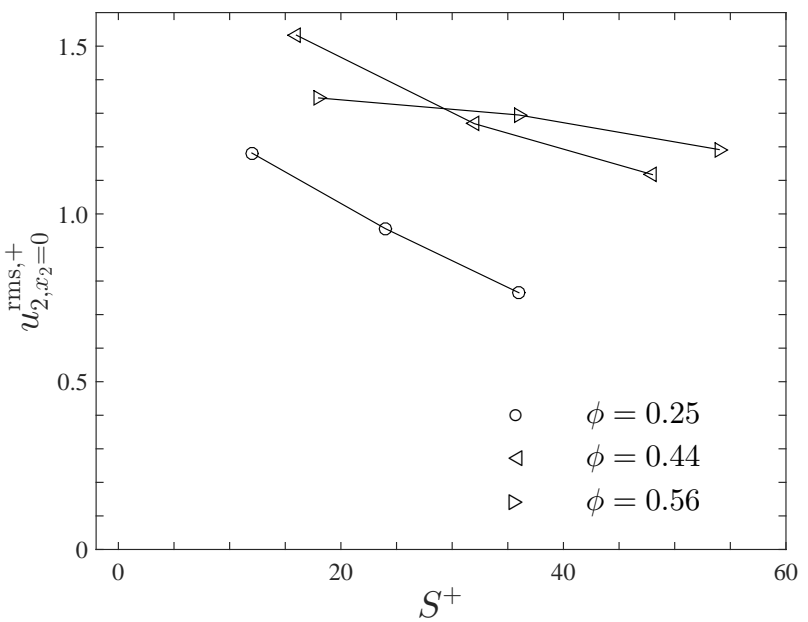

図-5 メッシュ境界空隙を過ぎる速度 $u_{2}$ の乱れ強度の境界幾 何学特性依存性.

平面での時空間平均によって得られた。 ケース M44-16 と M56-18における大小関係が逆な点を除けば, 空隙率 $\phi$ が高いほど, および空隙サイズ $S$ が小さいほど, 吹 き出し/吸い込み強度が強い傾向が認められる. 図-2 と 併せて考えると, 抵抗が強いケースほど吹き出し/吸い 込久強度が高いことがわかる. 同様の関係は 2 次元直 線流路中央に設置された円柱列を過ぎる流れにおいて も報告されている6). 


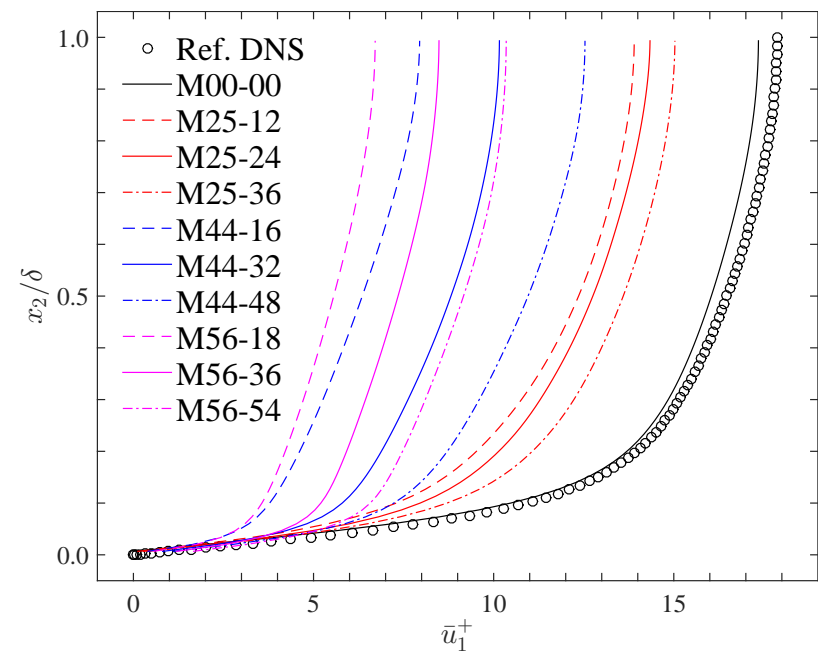

(a) linear plot.

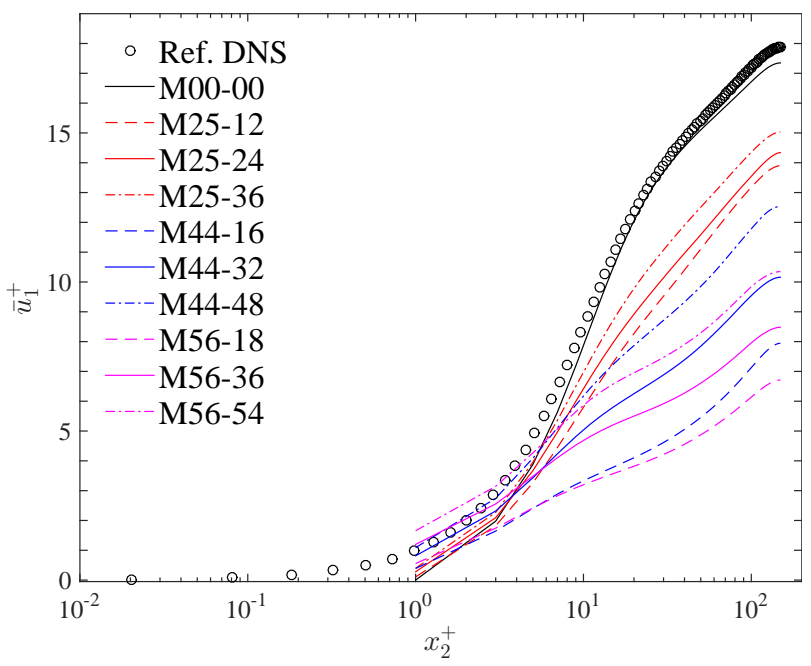

(b) semi-log plot.

図-6 平均流速のメッシュ境界幾何学特性依存性.

\section{4. 乱流統計量}

3 節では主に瞬時流れ特性のメッシュ境界の幾何学形 状に対する依存性に注目して議論を行った。ここでは 平均流速に代表される乱流統計量に境界の透過性が及 ぼす影響を検討する。

図-6 は主流速のアンサンブル平均值の線形および片 対数プロットを, 図-7 は乱れ強度分布の主流方向およ び境界法線方向成分をそれぞれ表す。ここでは参照デー タとして, Iwamoto et al. ${ }^{8)}$ による通常のチャネル乱流 DNS 結果 $\left(R e_{\tau}=150\right)$ も併せて表示した。また，これ らの統計量は図-5 とは異なり, 流体相と固相を区別せ ずに巨視的な立場から評価したものであることに留意 されたい.

IB 法で再現した通常チャネル乱流（M00-00）とその 参照 DNS データ 8) を比較すると, 平均流速分布は概称 一致するものの, 乱強度分布, 特にその横断方向成 分 $u_{3}^{\text {rms }}$ について IB 法に基づく結果が参照 DNS データ から乘離する.これは主に, 今回の数值実験で用いた, 計算領域全体で一様に与えた 2 粘性長という計算格子 間隔が壁面極近傍の現象を定量的に再現するには十分

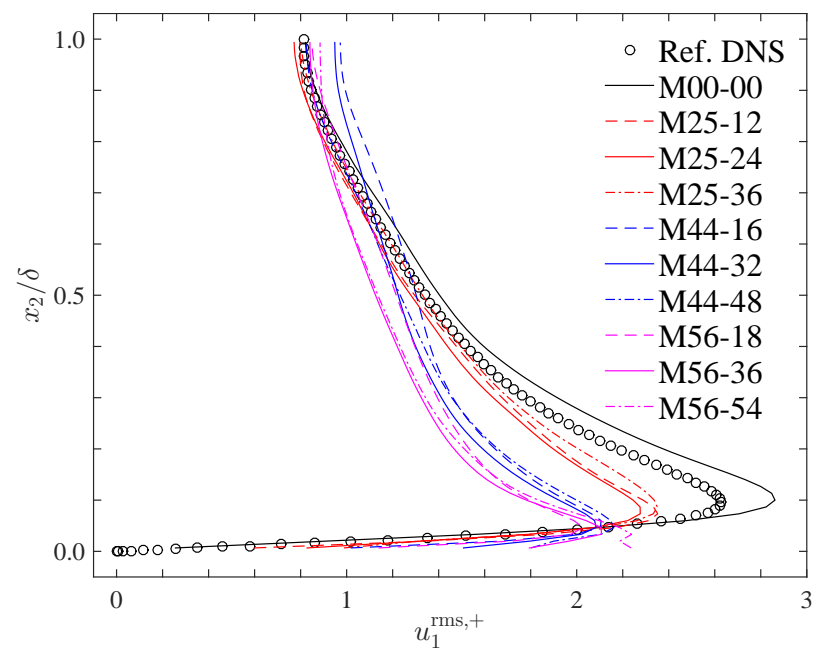

(a) streamwise component.

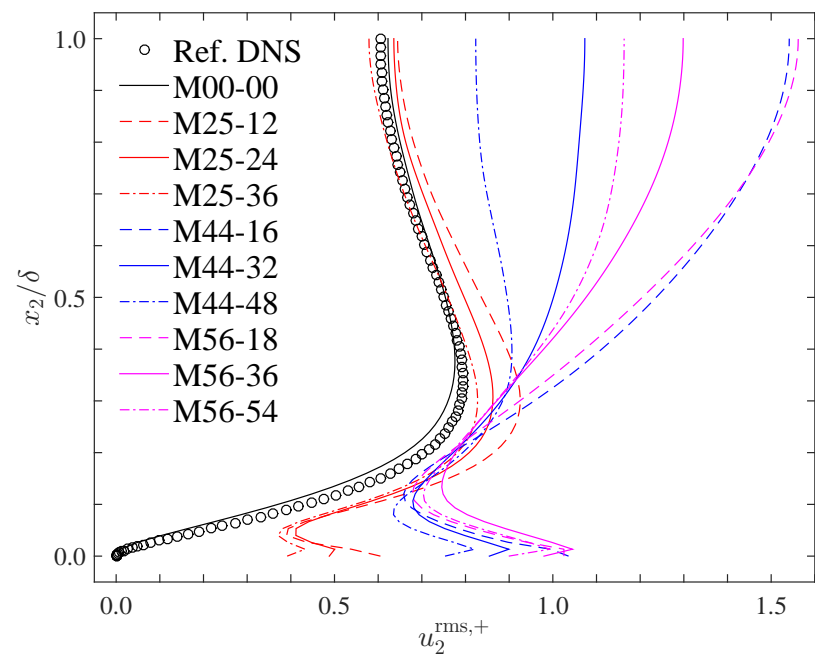

(b) component normal to mesh-screen plate.

図-7 乱れ強度のメッシュ境界幾何学特性依存性.メッシュチャ ネル流ではいずれの成分も境界上 $\left(x_{2}=0\right)$ で非ゼロな 值をとる.

ではないためと考えられる。この影響は平均流速分布 の壁からの第 1 格子点 $\left(x_{2}^{+}=1\right)$ での值の過少評価に も認められる（図-6(b)）。他方で流れのコア領域での平 均流速分布は参照 DNS データの振る舞いを大まかには 再現できており，流量は約 3\% の誤差で一致する. 図-3 で可視化された瞬時渦構造についてもこれまでの壁乱 流の知見との矛盾は認められず，3節で展開された議論 は定性的には成り立つと期待される.

巨視的な観点から興味深い透過性境界の特徵量のひ とつに境界接線方向のすべり速度が挙げられる. 境界か らの第 1 格子点 $\left(x_{2}^{+}=1\right)$ における平均主流速 $\bar{u}_{1}$ （図6(b)）に基づけば, 主流方向のすべり速度は境界の空隙 率 $\phi$ とともに増加し, また空隙サイズが大きいほど増 加する. また, 乱れ強度の境界法線方向成分 $u_{2}^{\mathrm{rms}}$ の境 界上での值は巨視的な吹き出し/吸い込みの程度を表し, 重要な特徵量である. この巨視的な吹き出し/吸い込み 速度スケールは, 図-4で示された流体相のみのデータ に基づく乱れ強度と比べれば当然その值は小さいもの の, 空隙率 $\phi$ が高いほど, そして空隙サイズ $S$ が小さ 
いほど強まる点は図-4 と同様である.メッシュ境界の 空隙率が増して完全透過チャネル流に近づくにつれて, 境界近傍での乱れ強度の強い異方性が緩和され，断面 全体で一様化される方向に変化が認められる点は, 完 全透過チャネル流の結果 ${ }^{1)}$ とも整合する.

\section{5. おわりに}

本研究では境界の透過性が乱流場に及ぼす影響を明 らかにするため，主流に平行に設置されたメッシュ状 平板境界を過ぎる発達乱流場に関する数值実験を行っ た。本報では，メッシュ間隔 $S$ とメッシュ素材幅 $W$ を 同時にゼロに近づけた極限にあたる完全透過チャネル 流に関する先行研究 ${ }^{1)}$ の一般化として, 境界空隙率 $\phi$ と間隔 $S$ を系統的に変化させ，その影響を検討した。

4 節で示されたように，境界極近傍での境界法線方 向の空間解像度の不足のため, 本研究で得られた結果 から定量的な議論を行うことは時期尚早と推測される. 他方で本報で展開されたような，流れのマクロな特性 に関する定性的な議論は可能と考える. その理由のひ とつに, 本研究で観察された流れのマクロ特性のメッ シュ境界の幾何学特性に対する依存性が, 透過境界の 両極限にあたる通常の不透過なチャネル乱流および完 全透過チャネル流における知見 ${ }^{1)}$ と整合することが挙 げられる。これは, 完全透過チャネル流で観察された, 通常のチャネル流とは全く異なる力学機構の存在 ${ }^{1)}$ が 極限理想状態でのみ生じる特異なものではなく，より 細い素材を用いてより目の細かなメッシュ構造を導入 することで実現し得ることを示唆する．すなわちメッ シュ・チャネル流は, 通常のチャネル流と完全透過チャ ネル流という, 層流条件下では同一解を有するものの 乱流状態では全く異なる振る舞いを示す2つの系を結 びつけ，その質的な特性変化の原因解明に寄与し得る， より一般性を備えた壁境界と捉えられる.
本研究で得られた知見を定量的なレベルで確立し, 透 過性の付加による抵抗増大のメカニズムとそれに対す る境界粗度の影響を解き明かすためには, 境界極近傍 でさらに高い解像度を確保するとともに, 空隙率 $\phi$ と 空隙サイズ $S$ をより広範に変化させた検討が必要不可 欠であり，今後の課題である.

\section{参考文献}

1) Yokojima, S.: Effect of wall permeability on wall-bounded turbulent flows, J. Phys. Soc. Jpn., Vol.80, 033401, 2011.

2) Uhlmann, M.: An immersed boundary method with direct forcing for the simulation of particulate flows, J. Comput. Phys., Vol.209, pp.448-476, 2005.

3) Kempe, T. and Fröhlich, J.: An improved immersed boundary method with direct forcing for the simulation of particle laden flows, J. Comput. Phys., Vol.231, pp.3663-3684, 2012.

4) 横嶋 哲, 野田博, 河原能久: 円柱群を過ぎる 2 次元流れの 抗力特性, 土木学会論文集 B1（水工学）, 70(4), pp.I_829I_834, 2014.

5) 横嶋 哲, 浅岡 亮介, 宮原 高志: 2 次元直線水路内に設置さ れた円柱列の抗力特性, 土木学会論文集 A2 (応用力学), 70(2), pp.I_785-I_792, 2014.

6) 横嶋 哲, 浅岡 亮介, 宮原 高志: 2 次元直線水路中央に設置 された円柱列の抵抗最大化現象のスケーリング, 土木学会 論文集 B1（水工学）, 71(4), pp.I_1057-I_1062, 2015.

7) 横嶋 哲, 高島 立, 宮原 高志: 粒子群の沈降挙動に粒子形状 が及ぼす影響, 土木学会論文集 A2（応用力学）, 印刷中.

8) Iwamoto, K., Suzuki, Y. and Kasagi, N.: Reynolds number effect on wall turbulence: toward effective feedback control, Int. J. Heat Fluid Flow., Vol.23, pp.678-689, 2002.

(2015.9.30 受付) 